\title{
Habitat Based Feeding Practices in Wild pigs (Sus scrofa) and pork in Vietnam (Thai Nguyen region)
}

\section{Bui Thi Thom², Nguyen Thi Hang ${ }^{2}$, Dinh Tran Ngoc Huy ${ }^{*}$, Vu Quynh Nam4}

${ }^{1}$ Thai Nguyen University of Agriculture and Forestry, Vietnam

${ }^{2}$ Thai Nguyen University, University of Information and Communication Technology, Vietnam

${ }^{3}$ Banking University HCMC, Ho Chi Minh city Vietnam International University of Japan, Japan

${ }^{4}$ National Economics University (NEU), Hanoi, Vietnam

Study Area: Hanoi, Vietnam

Coordinates: $21^{\circ} \mathrm{O1}^{\prime} 42^{\prime \prime} \mathrm{N} 105^{\circ} 51^{\prime} 15^{\prime \prime} \mathrm{E}$

Keywords: Pig farming, Omnivorous, Protein requirement.

Policy implications:

Ministries and government agencies would implicate its directions to facilitate export markets for wild pork meat in the northern region of Vietnam, for instance, in Thai nguyen city, esp. In the context during EVTA to help pork meat export to the European market.

And Huy, D.T.N (2015) also suggest management standards for better management of businesses in various sectors including agriculture.

\section{Abstract}

Wild boars are omnivores and sometimes eat indiscriminately; it survives in many different environments, from deserts to mountainous areas. This study used qualitative analysis, synthesis and inductive methods, with statistic data, examined experiences from Asian countries such as Thailand and China and meanings to Vietnam case of feeding wild pigs. Our results identified the amino acid requirement of pigs consists of two components, maintenance needs and production needs. Last but not least, through our analysis, authors suggest Ministries and government agencies consider facilitating export markets for wild pork meat in the northern region of Vietnam, for instance, in Thai Nguyen city. In the context during EVTA to help pork meat export to the European market. With the practical requirements of Vietnam's wild boar farming and natural conditions, the research to determine the reasonable protein level in the diet based on local feed ingredients is an urgent requirement. Solving this urgent scientific problem not only ensures the maintenance of good growth performance for wild boars and hybrids but also has the meaning of saving and taking initiative in food sources in large-scale wild boar and hybrid breeding. In particular, it contributes to preserving and protecting precious piggenetic resources.

www.baodautu.vn, date24/6/2021).

As per Pligne et al., (2001) Boucane' is a traditional meat product from Reunion that is obtained by salting, drying and hot smoking pork belly. Thanapongtharm (2016) reported that the pig production in Thailand intensified significantly during the last decade, with many economic, epidemiological and environmental implications. As per Thang \& Van (2006), there are different types of feeds, different diets, thus the content of nitrogen forms in the intestinal chyme is different. When the boar gets mature (around $50-350 \mathrm{~kg}$ ) it leaves the herd and lives independently with some domesticated pigs $(\sim 450 \mathrm{~kg})$. Males are usually larger than females. Wild pigs have 4 pairs of fangs and 6 pairs of breasts (Hang, 2008). It played a central role in the subsistence and culture of China for millennia (Lander et al., 2020).

Our study is to answer the following: What is the appropriate feeding mechanisms of wild pigs, and to know the protein and amino acid requirements? What are food processing and recommendations? total export value of Vietnam to EU (source: 
Methodology: A combination of quantitative methods and qualitative methods including synthesis, inductive and explanatory methods.

\section{Results:}

Overview on Characteristics of growth and sexual development of wild boars and hybrids: Wild boars grow with the slow trends and reach their maximum size depending on breed, environment and age. The European wild boar is usually much larger in stature than the Asian wild boar. While the Asian wild boar can only be $65-70 \mathrm{~cm}$ tall, 120-140 cm long, 70-150 kg in weight, the European wild boar can be up to $90-100 \mathrm{~cm}$ tall, $150-160 \mathrm{~cm}$ long, and weigh up to 200-350 kg. Males are usually 20-30 kg larger than females (Markina et al., 2004). Newborn pigs are very small, weighing $0.5-0.7 \mathrm{~kg}, 15-25 \mathrm{~cm}$ long. Weaning age 5560 days; The weight of piglets at weaning is $4-5 \mathrm{~kg} / \mathrm{head}$. The age of slaughter can be calculated from 8 to 10 months old; the weight usually ranges from $25-35 \mathrm{~kg}$ depending on the needs of the market (Gardner et al., 2013).

Table-1 : Wild pigs growth rate

$\begin{array}{lll}\text { Monthage } & \text { Weight }(\mathrm{kg}) & \text { Speed of growing (g/days) } \\ 0-2 & 0.5-5 & 8.33-83.33 \\ 2-4 & 10-12 & 166.66-200,00 \\ 4-6 & 15-25 & 250.00-416.66 \\ 6-8 & 25-35 & 300.00-583.33 \\ 8-10 & 40-50 & 666.66-833.33\end{array}$

The growth rate (for wild boars that have been raised in Thailand and Vietnam) is slow (average is only about 0.15 $0.3 \mathrm{~kg} /$ day). The physiological life span of wild boar lasts from 15 to 25 years (Thanapongtharm et al., 2016; Chen et al., 2018).

\section{Food and feeding method:}

- Food is full of nutrients, not rancid, mouldy.

- The daily intake of pregnant sows depends on the sow's condition. Skinny sows must increase feed, too fat sows must reduce mixed feed but must increase forage (Geisser \& Reyer, 2004).

- In winter, when the temperature in the barn is $<150 \mathrm{C}$, sows need to eat more (0.2-0.3 kg/day) to compensate for the energy lost due to cold resistance (Knox, 2014).

Basic characteristics of the digestive physiology of pigs: omnivores; the gastric environment contains gastric juice secreted by the gastric glands. The gastric juice has a low $\mathrm{pH}$ environment suitable for pepsin activity to break down proteins intoalbumin, peptone products and a small number of aminoacids (Phùng etal., 2004). The pig's small intestine is very long and has many digestive secretions such as pancreatic juice, intestinal juice and bile, in which only pancreatic juice and intestinal juice contain enough enzymes to thoroughly digest nutrients in feed. Therefore, the small intestine is a digestive part full of enzymes that break down nutrients in food into the simplest nutrients, helping the body absorb directly through the intestinal wall into the bloodstream. Bile juice does not contain digestive enzymes, but it aids in digestive activities, especially fat digestion. The small intestine environment is alkaline and has a special structure, highly adapted to digestion and absorption of food.

Along the intestinal mucosa, there are developed intestinal glands that secrete intestinal secretions in a fullsecretory fashion, that is, the glandular cells filled with enzymes fall directly into the intestinal cavity, creating an endogenous nitrogen source up to $30 \mathrm{~g} /$ day. This is a feature that affects the accuracy of the digestibility test results in pigs, which cannot be ruled out. In the large intestine of pigs, there is a symbiotic intestinal microflora in the cecum and colon that is capable of breaking down fibres. The large intestine does not secrete enzymes but only continues to break down food by enzymes in the small intestine. This rate of digestion is high or low depending on the retention time in the large intestine (12-16 hours) (Extracted from Phùng et al., 2004). Digestion fibre is 14\%, digest protein is $12 \%$, have $9 \%$ carbohydrates and $3 \%$ lipids of the remaining nutrients digested by the large intestine. The main activity of the large intestine is the fermentation of fibre due to the action of the microflora in the cecum and colon and the decomposition of excess protein in food by rotten bacteria to form Crezon toxins. Fenol, Idol, Scatol. These toxins are absorbed into the bloodstream and detoxified in the liver. If these substances are too much, they will poison the liver and be excreted through faeces, causing unpleasant rotten odours, polluting the environment, and also cause diarrhoea in pigs (Thang et al., 2006).

Thus, in all cases, fermentation by microorganisms in the caecum and colon of pigs produces microbial biomass that is excreted in the faeces, and this nitrogen source, together with excess nitrogen in the feed, causes significant errors. Important in determining the net digestibility of nitrogen in feed. This compels nutritionists to study exclusions in experimental methods to test digestibility. The digestive activity of pigs during the day is usually greater than at night, and the time the feed stays in the gastrointestinal tract in pigs is about 24 hours. However, there is a small portion of food that will be discarded in about 4-5 days (Phùng et al., 2004).

Protein and amino acid requirements of pigs: these in pigs consists of two components, maintenance needs and production needs. Recognize that maintenance is not a physiological reality but a conceptual fit (Fuller, 1989).

In mature individuals this also means constant body mass, however, in immature animals the mass is kept constant by keeping nutrition, promoting growth and continuing to increase body protein, while body fat loss (Fuller et al., 1979).

To maintain nitrogen balance it is necessary to supply amino acids at a rate equal to the rate at which they are lost 


\section{TECHNOSCIENCE ARTICLE}

through metabolism, secretion or excretion from the body. Mandatory loss processes arise through them, the following processes being the most important and quantitative in nature.

Synthesis of non-protein substances: some of the essential amino acids cannot be used in the synthesis of physiologically important substances such as Hormones, neurotransmitters and important products of biological transformation side. essential complementary amino acids are lysine, methionine (and cysteine), phenylalanine (primarily through tyrocine), histidine, and tryptophan (Murphy \& Pearcy, 1993).

Aminoacids lost from epidermal cells: Loss of amino acids from epithelial cells occurs free amino acids and proteins. Since pigs are non-per spirants, loss through perspiration is expected to be minimal. In particular, skin and hair shed and are replaced continuously, estimated skin and hair nitrogen loss in pigs averaged $55 \mathrm{~kg}$ for a range of $0.25-0.50$ $\mathrm{g} / \mathrm{d}$, depending on feeding. and ambient temperature. By extrapolation (Fuller, 1991) it is estimated that if the feed were restricted to such a degree to stop growth, these losses would be reduced to approximately $1 \mathrm{~g} \mathrm{~N} / \mathrm{d}$ or 5 $\mathrm{mg} / \mathrm{d}$. This is only about $2 \%$ of the total $\mathrm{N}$ that needs to maintain. However, this estimate, which includes extensive extrapolation, is unlikely to be a direct estimate.

In contrast, much of this is dependent on proteolysis and a large proportion of amino acids are reabsorbed, estimates of minimal loss from the gastrointestinal tract have been carried out by determining amino acids. enter the large intestine when animals are fed a protein-free diet. In a nutshell, the maintenance requirement is the amount of protein that replaces the proteins that are required to be lost from the body consisting mainly of skin proteins and various nitrogen metabolism end products in the urine. Forced losses are generally assessed by determining nitrogen excretion when fed a protein-free diet and have a normal relationship to body mass. Whether or not this estimate is applicable, to animals fed diets with normal levels of protein in the feed (Thang et al., 2006).

Interaction relationship between protein and metabolic energy: studies suggested that the protein accumulation rate of pigs can be inhibited because the feeding process does not provide enough energy and protein. The rate of protein accumulation can be influenced relatively independently of the energy or protein the animal receives daily through food. When formulating diets for pigs, one must establish a balance between protein and energy in order to maximize protein accumulation and significantly reduce fat accumulation.

Changes in the content of some amino acids in the internal organs can be attributed to the energy and protein intake that affect blood and organ mass (Bikker et al., 1994), and related fractions increased with increasing energy intake. The mass of blood, kidney, pancreas and
Ambient Science, 2021: Vol. 08(2); 19-23 DOI:10.21276/ambi.2021.08.2.ta01

spleen also increased with increased protein intake (Excerpt from Giang, 1999), protein content in blood, digestive system and liver account for 5, 4 and $3 \%$ respectively compared with whole-body protein. Different levels of energy intake would greatly affect the content and composition of acids. The content of lysine, threonine, histidine, tyrosine, aspartic acid and serine in the internal organs are reported as $10-30 \%$ higher, while cysteine, leucine, phenylalanine valine was $40-50 \%$ higher than that in the carcass and the organs. The content of methionine, arginine, isoleucine, glutamic acid and glycine in the carcass was $10-30 \%$ lower than that of the organ.

\section{Discussion:}

All living, developing and reproductive activities of pigs are associated with the process of using and exchanging energy. Energy in food is stored in the physical forms of food such as fat, sugar, protein, and carbohydrates. Pigs receive food energy from the outside, through digestion, absorption in the digestive tract into the body and synthesis into fat, glucose, and pure protein of the pig's body.

The pig's body wants to function like walking, breathing, circulating, digesting, excreting etc. Heat energy turns into function and acts on the body's organs to function in a rhythmic manner, through the control of nerves, hormones, and enzymes. Energy participates in the construction of nerve cells, nerve sheaths, forming important compounds such as lipoproteins, glycoprotein found in nerve cell membrane tissue, in exocrine glands. Fat both stores energy and acts as a cushion under the skin, surrounding the digestive tract, circulation, and respiration to resist mechanical impact, heat and cold for the body. Pigs need more energy than other cattle because the genetic makeup of pigs accumulates fat about $45-50 \%$ (Thom et al., 2021).

The Results of evaluating the quality of experimental pork. In addition, the experiment also assessed meat quality through a number of criteria presented in Table-2.

Table-2: Results of evaluation of experimental pork quality

\begin{tabular}{|c|c|c|c|}
\hline \# Content & $\begin{array}{l}\text { Lot TN1 } \\
X \pm \mathrm{m}_{x}\end{array}$ & $\begin{array}{l}\text { Lot TN2 } \\
X \pm \mathrm{m}_{x}\end{array}$ & $\begin{array}{l}\text { Lot } \mathrm{TN}_{3} \\
X_{ \pm} \mathrm{m}_{x}\end{array}$ \\
\hline $\begin{array}{l}\text { 1. Meat color after surgery } \\
(\text { Minolta L*) (brightnes) }\end{array}$ & $48.02 \pm 1.11$ & $47 \cdot 95 \pm 1.54$ & $47.83 \pm 1.36$ \\
\hline 2. Meat toughness $\left(\mathrm{kg} / \mathrm{cm}^{2}\right)$ & $4.85 \pm 1.23$ & $4.89 \pm 1.56$ & $4.95 \pm 1.25$ \\
\hline $\begin{array}{l}\text { 3. } \mathrm{pH} \text { of tenderloin right after } \\
\text { surgery }\end{array}$ & $6.8 \pm 0.32$ & $7.0 \pm 0.12$ & $7.1 \pm 0.15$ \\
\hline 4. Tenderloin $\mathrm{pH}$ after $45 \mathrm{~min}$. & $5 \cdot 5 \pm 0.21$ & $5.3 \pm 0.24$ & $5.2 \pm 0.26$ \\
\hline 5. Cholesterol $(\mathrm{mmol} / \mathrm{L})$ blood & $1.65 \pm 1.23$ & $2.15 \pm 0.91$ & $3.11 \pm 1.89$ \\
\hline 6. Triglycerid (mmol/L) blood & $2.3 \pm 1.34$ & $2.8 \pm 0.98$ & $2.6 \pm 1.12$ \\
\hline
\end{tabular}

A lot of research in this field determining the protein and energy needs of pigs to promote growth, complete development, reduce costs and increase livestock 
efficiency have been carried out. The balance between protein/ME in pigs is an important requirement for growth, meat quality, and lean percentage at the growing stage of pigs.

Survey results on 77 wild boar breeding facilities across the country by the National Institute of Livestock Production showed that $61.1 \%$ of establishments raised pure Thai wild boar, $38.9 \%$ of establishments raised many types, including wild boar. Thailand, Vietnam, native pigs and hybrids. There are 6 establishments that also raise pure Vietnamese wild boar. The Thai wild boar is imported from Thailand. However, in the South, there are also Malaysian wild boars.

The balance of protein in the diet is a measure to supplement protein feed for wild boars, which is a measure to increase the efficiency of industrial-oriented hybrid wild boar farming to meet market demand. The research by Van de Ligt et al. (2002), Thong \& Liebert (2004) on the balance of amino acids and proteins in foreign crossbred pigs have been done. Meat farming has given good results. Thus, the balance of protein and energy levels for hybrid wild boar to assess the growth ability through the stages, both to exploit the growth ability of high-quality wild boar and to ensure naturalness. Their wildness is suitable for the northern climate conditions of Vietnam.

Kvisna et al. (2005) studied the process of raising wild boar in Thailand got good results. Besides, Litten et al. (2004); Kuhn et al. (2004) also studied that the addition of cassava flour to the wild boar's diet was effective but increased the percentage of fat higher than the addition to the corn-only diet.

Conclusively, the practical requirements of Vietnam's wild boar farming and natural conditions, the research to determine the reasonable protein level in the diet based on local feed ingredients is an urgent requirement. Solving this urgent scientific problem not only ensures the maintenance of good growth performance for wild boars and hybrids but also has the meaning of saving and taking initiative in food sources in large-scale wild boar and hybrid breeding. big is easy. In particular, it contributes to preserving and protecting precious pig genetic resources.

\section{References:}

Ballari, S.A., \& Barrios-García, M.N. (2014): A review of wild boar Sus scrofa diet and factors affecting food selection in native and introduced ranges. Mamm. Rev., 44(2):124-134.

Bikker, P., Verstegen, M.W., \& Bosch, M.W. (1994): Amino acid composition of growing pigs is affected by protein and energy intake. J. Nutr., 124(10):1961-1969.

Chen, J., Ni, P., Tran Thi, T.N., Kamaldinov, E.V., Petukhov, V.L., Han, J., Liu, X., Šprem, N. \& Zhao, S. (2018): Selective constraints in cold-region wild boars may defuse the effects of small effective population size on molecular evolution of mitogenomes. Ecol. Evo., 8(16):8102-8114.

Fuller, M.F. (1991): Protein Metabolism and Nutrition. Proceeding of the 6th International Symposium on Protein
Metabolism and Nutrition, pp. 116-126. Edited by B.O. Eggum, S. Boisen, C. Borsting, A. Danfear and T. Hvelplund. Pub. by: E.A.A.P. Publication No. 59. Foulum: National Institute of Animal Science.

Fuller, M.F., Menie, I., Crofts, R.M.J. (1979): The acid amin supplementation of barley for the growing pig", 2, Optimal additions of lysine and threonine for growth. Br. J. Nutr., 11:4166.

Fuller, M.F., R.McWiliam, T.C.Wang, \& L.R.Giles (1989): The optimum dietary acid amin pattern for growing pigs, 2 . Requirements for maintenance and for tissue protein accretion. Br.J. Nutr., 62:255-267.

Gardner, J.A.A., Dunkin, A.C., \& Lloyd, L. C. (Eds.). (2013): Pig Production in Australia. Pub. by: Elsevier.

Geisser, H., \& REYER, H.U. (2004): Efficacy of hunting, feeding, and fencing to reduce crop damage by wild boars. J. Wildlife Manag., 68(4):939-946.

Giang, V.D., Hong, N.T.L. \& Son, T.T. (1999): Nutrition and Fodder. Pub. by: Agriculture Publishing House, Hanoi.

Hang, D.L. (2008): Some basic biological characteristics of wild boar. Livestock magazine.

Hang, N.T., Tinh, D.T., Huy, D.T.N., \& Nhung, P.T.H. (2021): Educating and training labor force Under Covid 19; Impacts to Meet Market Demand in Vietnam during Globalization and Integration Era. J. Educ., Teach. Train., 12(1).

Hao, P.X. (2007): Evaluation of growth, yield and meat quality in Landrace, Yorkshire and F1 pigs (Landrace x Yorkshire). L. Agricul. Sci., V(1):31-35.

Huy, D.T.N. (2012): Estimating beta of Viet Nam listed construction companies groups during the crisis. L. Integr. Develop., 15(1):57-71

Huy, D.T.N. (2015): The critical analysis of limited South Asian Corporate Governance Standards after financial crisis. Int. J. Qual. Res., 9(4):741-764.

Huy, D.T.N., An, T.T.B., Anh, T.T.K. \& Nhung, P.T.H. (2021): Banking sustainability for economic growth and socioeconomic development-case in Vietnam. Tur. J. Comp. Math. Edu., 12(2): 2544-2553.

Huy, D.T.N., An, T.T.B., Anh, T.T.K., \& Nhung, P.T.H. (2021): Banking sustainability for economic growth and socioeconomic development - case in Vietnam. Turk. J. Comp. Math. Edu., 12(2):2544-2553

Huy, D.T.N., Dat, P.M., và Anh, P.T. (2020): Building and econometric model of selected factors' impact on stock price: a case study. L. Sec. Sustain. Iss., 9(M):77-93.

Huy, D.T.N., Loan, B.T. \& Anh, P.T. (2020): Impact of selected factors on stock price: a case study of Vietcombank in Vietnam. Entrepren. Sustain. Iss., 7(4):2715-2730.

Huy, D.T.N., Nhan, V.K., Bich, N.T.N., Hong, N.T.P., Chung, N.T. \& Huy P.Q. (2021). Impacts of internal and external macroeconomic factors on firm stock price in an expansion econometric model - a case in Vietnam Real Estate Industry. Data Sci. Fin. Eco. Stud. Comp. Int., 898.

Keenan, D.F. (2016): Pork meat quality, production and processing on. 2016:419-431

Khwaja, A. \& Mian, A. (2005). Unchecked intermediaries: price manipulation in an emerging stock market. J. Finan. Eco., 78:243-241.

Knox, R.V. (2014): Impact of swine reproductive technologies on pig and global food production, pp.131-16o. In: Current and 
TECHNOSCIENCE ARTICLE

Future Reproductive Technologies and World Food Production. Pub. by: Springer, New York, ?

Kuhn, G., Kanitz, E., Tuchuscherer, M., Nurnberg, G., Hartung, M., Ender, K., Rehfeldt, C. (2004): Growth and carass quality of offspring in respose to porcine somatotropin (pST) treatment of sows during early pregnancy. Livestock Prod. Sci., 85:103-112.

Kvisna, K. \& Xrium-Thailan, P.K. (2005): Technical process of breeding and developing wild boar (Translation by Le Van Hien and Le Tuan Tu).

Litten J.C., Corson, A.M., Hall, A.O. \& Clarke, L. (2004): The relationship between growth performance, feed intake, endocrine profile and carcass quality of different maternal and paternal of pig. Livest. Prod. Sci., 89:33-39.

Luu, T.X., Loan, T.T., Su, V.V., Thanh, N.T. \& Ngoc, T.P. (2010): Some biological characteristics of imported Thai wild boar and Vietnamese wild boar. J. Sci. Technol., 25:12-19.

Markina, F.A., Sáez-Royuela, C.A.R.L.O.S., \& De Garnica, R.A.F.A.E.L. (2004): Physical development of wild boar in the Cantabric Mountains, Álava, Northern Spain. Galemys, 16:25-34.?

Marsico, G., Rasulo, A., Dimatteo, S., Tarricone, S., Pinto, F. \& Ragni, M. (2007): Pig, F1 wild boar x pig and wild boar meat quality. Ital. J. Anim. Sci., 6 (sup-1):700-703.

Morlein, D., Link, G., Werner, C. \& Wicke. M, (2007), "Suitability of three commercially produced pig breeds in Germany fora meat quality program with emphasis on drip loss and eating quality. Meat Sci., 77:504-511

Murphy, M.E., \& Pearcy, S.D. (1993): Dietary amino acid complementation as a foraging strategy for wild birds. Physiol. Behav., 53(4):689-698.?

Noi, N.V. (2010): Research on polymorphisms of some genes that regulate growth and meat production ability of pigs crossed between Thai forest and Pac Nam local sows, Master's thesis in agriculture, School of Agriculture and Rural Development. Thai Nguyen Unive. Agricul. Forest., 45-50.

Phùng, L.D. \& Nguy?t, H.T. (2011): Research on appearance, living habits, ability and reproductive behavior of imported Thai wild boar raised in central Vietnam. J. Sc., Hue Univer., 67:2011.
Ambient Science, 2021: Vol. 08(2); 19-23 DOI:10.21276/ambi.2021.08.2.ta01

Phùng, T.V., Hi?n, T.Q., Vân, T.T. \& H?o, H.T. (2004): Textbook of pig breeding (University). Pub. by: Agriculture Publishing House, Hanoi,

Pligne, I., Colignan, A. \& Trystram, G. (2001): Characterization of traditional processing of pork meat into boucane, Meat Sci., 59:377-389.

Schneider, M. (2014): China's Pork Miracle? Agribusiness and Development in China's Pork Industry. Pub. by: Global Meat Complex: The China Series.

Son, T.T., Mai, N.T. \& Hang, N.T.L. (2006): Textbook of nutrition and pet food. Pub. by: Hanoi Agricultural Publishing House.

Thanapongtharm, W., Linard, C., Chinson, P., Kasemsuwan, S., Visser, M., Gaughan, A. E., Epprech, M., Robinson, T.P. \& Gilbert, M. (2016): Spatial analysis and characteristics of pig farming in Thailand. BMC Veterin. Res., 12(1):1-15.

Thang, H.T. \& Van, C. (2006), Textbook of animal physiology, Pub. by:Agricultural Publishing House.

Tisdell, C.A. (2013): Wild pigs: environmental pest or economic resource? Pub. by: Elsevier.?

Toan, L.Q., Nguyen-Viet, H., \& Huong, B.M. (2013). Risk assessment of Salmonella in pork in Hanoi, Vietnam. Vietnam. J. Prevent. Med., 23(4):10-17?

Ton, V.D. \& Thang, P.D. (2009): Distribution, characteristics and productivity of Ban pigs raised in Hoa Binh province. J. Sci. Devel., 7 (2):180-185.

Van de Ligt C. P. A., Lindemann M.D. \& Cromwell, G.L. (2002): Assessment of chromium tripicolinate supplementation and dietary protein level on growth, carcass, and blood criteria in growing pigs. J. Ani. Sci., 80:2412-2419.

Vietnam Livestock Association (2002): Pig Breeding Manual Pub. by: Hanoi Agricultural Publishing House.

Wang, H.S., Xia, T., \& Guan, Z. (2018): Market power and food safety in the China pork industry: Agribusiness 35(9).

Wang, T.C. \& Fuller, M.F. (1990): The effect of the plane of nutrition on the optimum dietary amino acid pattern for growing pigs. Ani. Prod., 50:155-164.

Warriss, P.D. \& Brown, S.N. (1995): The relationship between reflectance EEL value and colour L" in pork loins. Anim. Sci., 61:145-147. 